UDC 338.124

DOI: https://doi.org/10.37320/2415-3583/21.8

\author{
Zaika Svitlana \\ Ph.D., Associate Professor \\ State Biotechnological University \\ ORCID: https://orcid.org/0000-0001-8132-7643
}

Kharchevnikova Liliia

Ph.D., Associate Professor State Biotechnological University ORCID: https://orcid.org/0000-0002-8035-126X

Zaika Olena

Higher Education Seeker State Biotechnological University ORCID: https://orcid.org/0000-0002-7921-3273

\title{
REENGINEERING OF BUSINESS PROCESSES AS A TOOL OF EFFECTIVE ENTERPRISE MANAGEMENT
}

In management, there are many management approaches that can improve the efficiency of the enterprise. At the same time, the priority of enterprise development is the implementation of innovative activities. To succeed in this area, companies are changing management approaches, organizational structures and business models. However, in the conditions of constant aggravation of competition, achievement of high indicators of activity of the enterprise is best provided at the expense of reengineering of business processes. The innovation of reengineering is that it combines the use of the prerogatives of computer technology, human resource management technology and business process change. In the current economic conditions, the speed of reaction of all subsystems of the enterprise and the efficiency of operations are of particular importance and are a necessary condition for its effective operation in conditions of constant competition. In this situation, reengineering is the most effective, because it helps to increase the efficiency of the enterprise by changing the business model it uses. Thus, the study of reengineering procedures, its principles and objectives is relevant today. The purpose of the study was to generalize theoretical approaches to the basic principles, types and objectives of business process reengineering as a tool for effective enterprise management. The methodological basis of the study was the work of domestic and foreign scientists on the problems of reengineering and change management. Business process reengineering is a thorough rethinking and radical redesign of business processes of companies that want to significantly improve their performance. It is used in cases when it is necessary to make an informed decision on the reorganization of activities: radical transformations, business restructuring, replacement of existing management structures with new ones, etc. Through the effective use of business process reengineering tools can make the company more flexible to changes in the environment and more resilient in a competitive environment. Thus, business process reengineering involves a decisive, radical restructuring of business processes and the foundations of management to significantly increase the competitiveness of the enterprise in the market and significantly increase the efficiency of the enterprise as a whole system.

Key words: reengineering, business processes, effective management, performance indicators, innovation.

JEL classification: M10, L10

Formulation of the problem. In today's conditions, the competition of enterprises for the markets is constantly intensifying, while enterprises are constantly improving the strategy of their activities, striving to ensure maximum efficiency at a minimum cost.

At present, enterprises have accumulated considerable experience in applying various concepts of management of their activities. In addition, modern management has been enriched with new approaches that allow us to consider the company from the standpoint of existing and existing business processes within it. The traditional organizational and functional structure of the enterprise has been replaced by a new approach based on the process model of its activity.

The concept of reengineering and its application can increase the efficiency of the enterprise, based on methods and techniques for identifying, describing, and redesigning existing business processes within the enterprise.

Analysis of recent research and publications. The founders of the concept of reengineering are M. Hammer and J. Champa [24], who noted that the competitiveness of enterprises can be achieved only through constant change and the application of new management techniques.

The concept of business process reengineering first came into practice and was perceived as a purely operational and management theory. This traditional approach did not reflect its true nature. In the works of domestic and foreign scientists, reengineering was considered an effective management tool designed to achieve a new level of quality of the enterprise. The vast majority of reengineering work is devoted to purely technical issues related to the description of business processes, their redesign, development of programs and methods of implementing new business processes, various reengineering techniques, and discussions about their disadvantages and advantages.

Among the foreign scientists who have made significant contributions to the study of reengineering and change management: Andersen B. [3], Binner H. [5], Ullah F. and Robson M. [23], Hammer M. and Champy J. 
[24], Harrington J., Esseling K. and Nimwegen H. Van [25] and others.

Domestic experts also studied various aspects of enterprise reengineering. Babak O. [4], Vinogradova O. [6], Griban S. [7], Ippolitova I. [9], Kovalev A. [10], Kohut Yu. [12], Kotlik A. [13], Krupa K. [14], Lepeiko T. [15], Lyubarska V. [16], Parsyak V. [18], Sakun L., Sukhomlin L., Riznichenko L. and Velkin B. [19], Sknar A. [20], Taranyuk L. [21; 22], Chornobay L. and Duma O. [26] and others devoted their works to these issues.

With the sufficiency of work on the research topic, the methods of reengineering to increase the efficiency of enterprises, the principles of reengineering business processes, and their classification remain insufficiently researched.

The purpose of the article is to generalize the theoretical approaches of domestic and foreign scientists to the purpose, principles, types, and main tasks of reengineering business processes of the enterprise as a tool for effective management.

Presenting main material. Changes in the conditions of doing business in Ukraine, caused by the European vector of economic cooperation, have set Ukrainian companies the task of increasing the competitiveness of products and services. The European market is oversaturated with modern goods and services, with which it is very difficult to compete with products of domestic manufacturers. To successfully enter the European market, it is necessary to improve not only the various characteristics of Ukrainian enterprises but also the relevant mechanisms of their management, as they often face the task of solving which with traditional knowledge and management paradigms is almost impossible.

The need to use new business models has led to an increasing number of managers looking for new nontraditional ways to achieve competitive advantage. One of these areas of management thought is the reengineering of business processes - a scientific theory formed in the early '90s of the twentieth century [11].

The priority direction of the development of modern economic science is a noticeable strengthening of paradigms and approaches focused on the innovative development of applied management technologies. Therefore, it is necessary to form such a scientific concept that would allow to design and implement large-scale projects. This will allow not only to increase the efficiency of their activities but also to introduce a fundamentally new business model.

The intensification of competition in the global and domestic markets has led to a special strategy of enterprises, for which the accumulation, reservation, and timely use of innovation has become a primary tool in the struggle for markets. Abroad, managerial innovations are being implemented everywhere, which are much cheaper than technological ones and are one of the main factors in increasing competitiveness in the world market. As an innovative management approach, enterprises need to more widely implement a process approach in management and master the methods of business process reengineering.

The technological revolution of recent decades has created an economic situation in which the potential supply in most markets significantly exceeds demand. This is due to a sharp increase in productivity, overproduction of goods and services, reduction of communication and trade barriers, improving living standards in developed market economies. As a result, relations between producers and consumers have changed, competition has intensified. Consumers have become not only demanding but also competent. On the other hand, the markets themselves have changed. They have become more transparent and open. In this situation, it is enough for the company to reduce the quality of goods or services, as it will immediately begin to lose its customer base [5]. But a successful company also needs to constantly improve, because everything positive in its work quickly becomes known to competitors.

However, internal factors are no less important. The fact is that any company after some time acquires a functional inconsistency or opacity. Production processes become more complicated, cumbersome, there is a deviation from the basic initial guidelines and priorities of activity, weakening motivation, and so on. The reasons for this may be the priorities of personal interests, staff turnover, and so on. Therefore, any company needs to transform the organizational structure and management methods, which is a complex task that applies to all areas of its activities. The use of such an innovative management approach as business process reengineering is an important and effective means of carrying out transformations in enterprises [15].

Reengineering means a radical change in the management structure, based on the optimization of internal business processes, minimizing costs, improving product quality, improving efficiency to ensure the competitiveness of enterprises in a dynamic environment [12; 22; 24].

The methodology of business process reengineering appeared more than 30 years ago and was initially aimed at achieving improvements in key performance indicators of the enterprise through its radical restructuring. However, most often the work was reduced to minor changes in business processes to gradually increase the efficiency of activities, rather than a fundamental transformation of the business. The reasons for this were the reluctance of employees and managers to carry out radical reorganization and limited opportunities for information technology. A distinctive feature of modern reengineering is the ability to reconstruct business processes throughout the enterprise without destroying the usual ways of doing business, which allows you to implement changes in a gradual evolutionary way [17].

The purpose of business process reengineering is:

- introduction of qualitatively better technological processes;

- significant reduction of production costs;

- increase productivity and reduce production time;

- introduction of automated control systems.

As a result, the company is undergoing radical changes to make it more competitive.

The founders of reengineering $M$. Hammer and J. Champa identified several of its main provisions [24]:

- restructuring of processes should take into account previous experience;

- reengineering requires a significant amount of innovation;

- radical changes are carried out based on the use of modern information technologies.

Thus, reengineering is based on some principles (Fig. 1) $[2 ; 3 ; 6]$. 


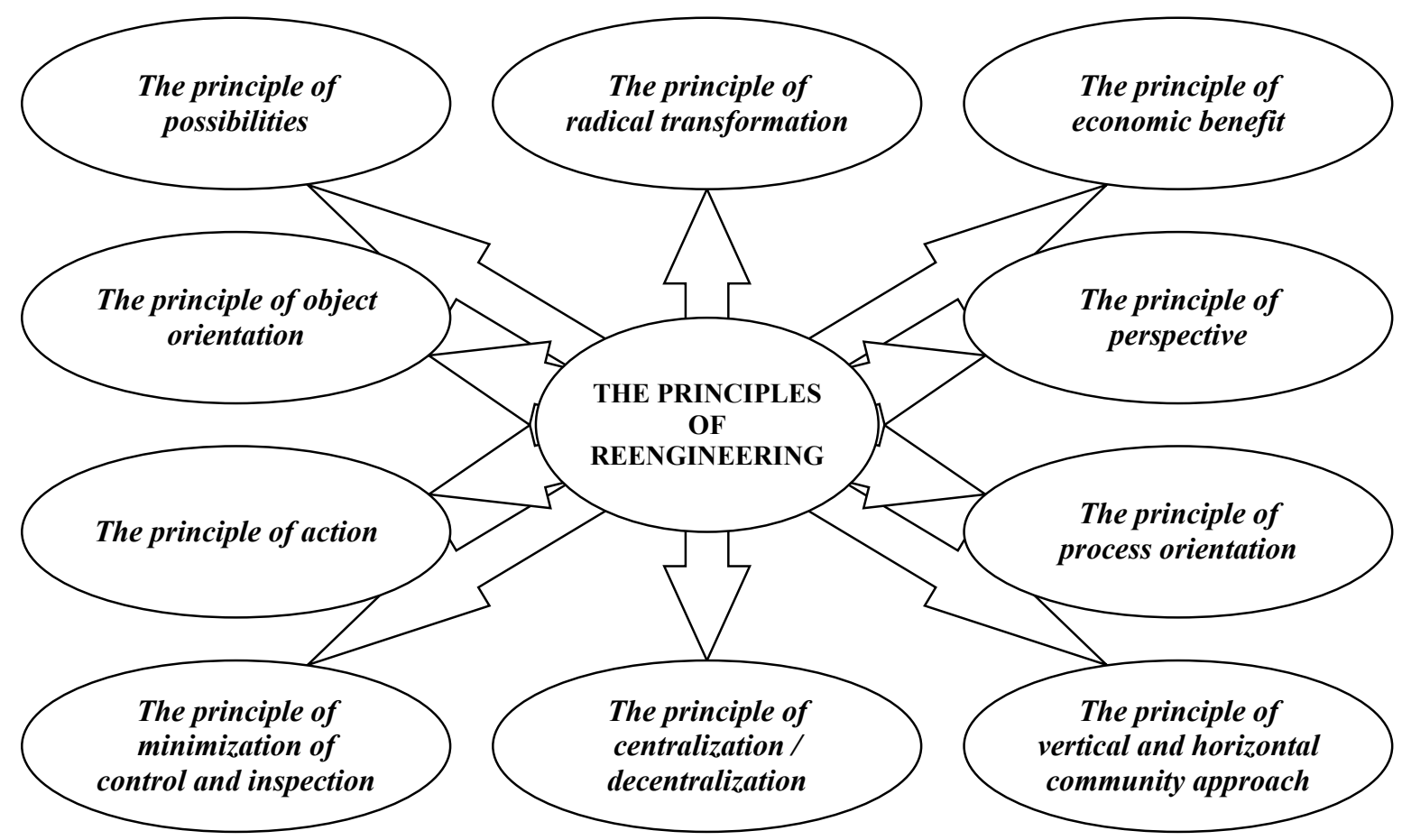

Figure 1 - Principles of reengineering business processes of enterprises

The principle of expediency: the main strategies can be developed only on the basis of careful analysis, identifying the determinants that determine the development of the enterprise, and the most likely trends in their change on the basis of established key factors that cause significant impact.

The principle of radical change: changing business processes are carefully designed to avoid the influence of customs and traditions that led to its current state.

The principle of object orientation: reengineering is aimed at objects and decomposes the enterprise in the framework of building a new model and redefining its business processes.

The principle of economic benefit: reengineering is based on the concepts of utility and cost.

The principle of perspective: reengineering is aimed at both existing processes and promising business processes.

Principle of participation: involvement of the external environment of the enterprise in its operation.

The principle of centralization/decentralization: the construction of the system is based on the decentralization of its subsystems, combining them with the general flow of information.

The principle of minimization of control and inspections: inspection and control operations do not add value. Therefore, their value should be prudently estimated concerning the cost of a possible error, which they are obliged to prevent or eliminate.

The principle of vertical and horizontal common approach: vertical common approach involves the coverage of all major areas of improvement of the enterprise. The horizontal commonality of the approach implies its application in the transformation of enterprises operating in different segments of the national economy.

Process orientation: the focus of reengineering on processes as the main aspects of the enterprise $[2 ; 3 ; 6 ; 15]$.
In practice, in addition to the principles of reengineering, often use recommendations for reengineering business processes, the main of which are $[5 ; 10]$ :

- reorganization of the enterprise in order to achieve results;

- integration of parallel business processes into a common process and centralized management;

- delegation of powers to the executors of the process;

- tracking business process information at its source.

The main requirements of reengineering for the processes to be reorganized are:

- attracting as few human resources as possible to the business process;

- simplicity of the business process;

- creating a significant number of ways to perform complex business processes;

- rational reduction of the number of entries in business processes;

- business process management using decentralization of powers;

- reducing the number of inspections and corrective organizational influences on the process.

As a rule, enterprises implement one of the types of business process reengineering, which is classified according to the type of their financial condition (Table 1).

The most costly is strategic reengineering. Opportunities for its implementation have high-tech enterprises and innovations that differ in operating in conditions of fierce competition.

Operational reengineering is carried out mainly by large enterprises. If they do not use development reengineering in time, they will have to use anti-crisis reengineering as a tool to overcome the difficult economic situation.

In the current economic conditions for many domestic enterprises today the most relevant is anticrisis reengineering, aimed at developing their concept 
Table 1 - Classification of types of business process reengineering $[6 ; 10 ; 12]$

\begin{tabular}{|l|l|}
\hline \multicolumn{1}{|c|}{ Financial condition of the enterprise } & \multicolumn{1}{c|}{ Type of business process reengineering } \\
\hline $\begin{array}{l}\text { Enterprises that do not have problems in current activities } \\
\text { and do not forecast them in the near future }\end{array}$ & $\begin{array}{l}\text { Strategic reengineering - is aggressive and aimed at gaining } \\
\text { strategic competitive advantage in order to maintain a leading } \\
\text { position in the market }\end{array}$ \\
\hline $\begin{array}{l}\text { Enterprises that do not have difficulties in current activities, } \\
\text { but anticipate the inevitable emergence of crisis situations }\end{array}$ & $\begin{array}{l}\text { Operational reengineering - is advanced in order to realize } \\
\text { the prospects of enterprise development, taking into account } \\
\text { the possibility of changes in the market }\end{array}$ \\
\hline Businesses on the verge of bankruptcy & $\begin{array}{l}\text { Crisis reengineering - aims to radically change business } \\
\text { processes to avoid bankruptcy }\end{array}$ \\
\hline
\end{tabular}

of enterprise development, given the limited available financial resources. The crisis management system is effective when it provides flexibility and adaptability of management, implements measures to strengthen informal management, provides a search for effective forms of management, and reduces centralization to respond quickly to emerging situations.

Thus, business process reengineering as a tool for effective enterprise management solves the following problems $[1 ; 6 ; 10-13]$ :

- develops horizontal management links, which contributes to the creation of a network of links for emergencies;

- creates organizational prerequisites for the centralization of information flows, which contributes to the receipt of information systematized for specific processes;

- promotes the separation of functions of senior management and the creation of a network of operational groups, which allows to use for these purposes the technology of work of process teams;

- determines the optimal sequence of functions performed, which leads to a reduction in the cycle of production and sale of goods and services, resulting in increased capital turnover and improved performance of the enterprise;

- motivates the creative approach, analyzes situations and teamwork, because on the basis of these principles the nature of work and the role of employees change;
- allows you to successfully combine strategy coordination from the center and decentralized implementation of decisions, as it is based on mixed processes and matrix management structures;

- creates organizational conditions for enterprise restructuring, as it connects changes in the management structure with the activities of process teams;

- streamlines the use of resources in various business processes in order to minimize costs and ensure the optimal combination of activities.

Conclusions. Reengineering of business processes of enterprises is used in cases when it is necessary to make an informed decision on the reorganization of activities: radical transformations, business restructuring, replacement of existing management structures with new ones, etc. An enterprise that seeks to improve its market position must constantly improve production technologies and methods of organizing business processes.

Effective use of business process reengineering tools will make the company more flexible to changes in the external environment and more resilient in a competitive environment.

Thus, business process reengineering involves a decisive, radical restructuring of business processes and the foundations of management to significantly increase the competitiveness of the enterprise in the market and significantly increase the efficiency of the enterprise as a whole system.

\section{References:}

1. Zaika S. (2021) Features of analysis of business processes of enterprises. Proceedings of the Upravlinnia resursnym zabezpechenniam hospodarskoi diialnosti pidpryiemstv realnoho sektoru ekonomiky: materialy VI Vseukrainskoi naukovo-praktychnoi Internet-konferentsii z mizhnarodnoiu uchastiu (Ukraine, Poltava, 17.11.2021), Poltava: PSAU, pp. 301-302.

2. Zaika O. (2021) Basic principles of business process reengineering. Proceedings of the Upravlinnia resursnym zabezpechenniam hospodarskoi diialnosti pidpryiemstv realnoho sektoru ekonomiky: materialy VI Vseukrainskoi naukovo-praktychnoi Internetkonferentsii z mizhnarodnoiu uchastiu (Ukraine, Poltava, 17.11.2021), Poltava: PSAU, pp. 329-330.

3. Andersen B. (2010) Biznes-processy. Instrumenty sovershenstvovaniya [Business processes. Improvement tools]. Moscow: Standards and quality. (in Russian)

4. Babak O. (2011) Reinzhynirynh yak suchasnyi instrument innovatsiinoi diialnosti pidpryiemstv [Reengineering as a modern tool for innovation of enterprises]. Proceedings of the Economic Bulletin of Pereyaslav-Khmelnytsky State Pedagogical University, no. $17 / 1$, pp. 55-60.

5. Binner H. (2010) Upravlenie organizaciyami i proizvodstvom: ot funkcional'nogo menedzhmenta k processnomu [Management of organizations and production: from functional to process management]. Moscow: Alpina Publishers (in Russian).

6. Vinogradova O. (2005) Reinzhynirynh biznes-protsesiv u suchasnomu menedzhmenti: monohrafiia [Reengineering of business processes in modern management: a monograph]. Donetsk.

7. Hryban S. (2015) Otsinka efektyvnosti reinzhynirynhu biznes-protsesiv yak instrumenta antykryzovoho upravlinnia [Evaluation of the effectiveness of business process reengineering as a tool for crisis management]. Proceedings of Agrosvit, no. 2, pp. 50-54.

8. S. Zaika, O. Gridin (2016) Osoblyvosti diahnostyky efektyvnosti menedzhmentu [Features of diagnostics of management efficiency]. Proceedings of the Bulletin of KhNTUA: Economic Sciences, no. 174, pp. 199-206.

9. Ippolitova I. (2016) Efektyvnist zdiisnennia reinzhynirynhu biznes-protsesiv na pidpryiemstvi [Efficiency of business process reengineering at the enterprise]. Proceedings of the Global and national economic problems, no. 13, pp. 264-270. 
10. Kovalov A. (2014) Pidvyshchennia efektyvnosti antykryzovoho upravlinnia v korporatyvnomu sektori na osnovi reinzhynirynhu biznes-protsesiv [Improving the efficiency of crisis management in the corporate sector based on business process reengineering]. Proceedings of the Bulletin of socio-economic research, no. 3 (54), pp. 124-130.

11. Kovtun T., Dmitrieva L. (2017) Reinzhiniring biznes-processov s pozicij metodologij upravleniya proektov [Reengineering of business processes from the standpoint of project management methodologies]. Proceedings of Management of the development of complex systems, no. 30, pp. 44-49.

12. Kogut Yu. (2011) Model reinzhynirynhu biznes-protsesiv pidpryiemstva [Enterprise business process reengineering model]. Proceedings of the Business Inform, Kharkiv, no.10, pp. 65-69.

13. Kotlik A. (2011) Pobudova systemy pokaznykiv dlia otsinky konkurentospromozhnosti biznes-protsesiv pidpryiemstva [Building a system of indicators to assess the competitiveness of business processes of the enterprise]. Proceedings of Development management, no. 21 (118), pp. 30-32.

14. Krupa K. (2011) Reinzhynirynh - hidna vidpovid na vyklyky otochennia [Reengineering is a worthy response to the challenges of the environment]. Proceedings of Current economic problems, no. 10, pp. 443-446.

15. Lepeiko T. (2009) Reinzhynirynh biznes-protsesiv [Business process reengineering]. Kharkiv: KhNEU (in Ukrainian).

16. Lyubarska V. (2004) Pravyla vydilennia biznes-protsesiv v orhanizatsii [Rules for allocating business processes in the organization]. Proceedings of Proceedings of the conference "Problems and prospects for the development of information systems and technologies in the economy", dedicated to the 40th anniversary of the Department of Information Systems. Development management, no. 2 , pp. $46-48$.

17. Maznev G., Zaika S., Gridin O. (2016) Antykryzove upravlinnia yak sfera biznes-administruvannia [Crisis management as a field of business administration]. Proceedings of Scientific Bulletin of Uzhhorod National University. Series: International Economic Relations and the World Economy», no. 10, pp. 25-32.

18. Parsyak V. (2011) Upravlinnia biznes-protsesamy - instrument pidvyshchennia efektyvnosti orhanizatsii [Business process management is a tool for improving the efficiency of organizations]. Proceedings of Current economic problems, no. 7, pp. 131-138.

19. Sakun L., Sukhomlin L., Riznichenko L., Velkin B. (2020) Reinzhynirynh biznes-protsesiv yak suchasnyi metod upravlinnia stratehichnymy zminamy na pidpryiemstvi [Business process reengineering as a modern method of managing strategic change in the enterprise]. Proceedings of Economics and organization of management, no. 2 (38), pp. 81-97.

20. Sknar A. (2009) Kontrolinhovi aspekty reinzhynirynhu biznes-protsesiv pidpryiemstva [Controlling aspects of reengineering business processes of the enterprise]. Proceedings of Banking, no. 3, pp. 81-87.

21. Taranyuk L. (2011) Metodolohiia reinzhynirynhu biznes-protsesiv promyslovykh pidpryiemstv [Methodology of business process reengineering of industrial enterprises]. Proceedings of The mechanism of economic regulation, no. 1, pp. 111-119.

22. Taranyuk L., Zaporozhchenko O. (2011) Orhanizatsiini zasady provedennia reinzhynirynhu biznes-protsesiv pidpryiemstva [Organizational principles of reengineering business processes of the enterprise]. Proceedings of The mechanism of economic regulation, no. 4, pp. 122-133.

23. Ullah F., Robson M. A Praktycheskoe rukovodstvo po reynzhynyrynhu byznes-protsessov [Practical Guide to Business Process Reengineering]. Electronic resource. Available at: http://iso.staratel.com/BPRI/ ReIngBP.htm.

24. Hammer M., Champy J. (2010) Reinzhiniring korporacii: Manifest revolyucii v biznese [Corporate Reengineering: A Manifesto for a Business Revolution]. Moscow: Mann, Ivanov and Ferber. (in Russian)

25. Harrington J., Esseling K., Nimwegen H. Wang (2011) Optimizaciya biznes-processov: dokumentirovanie, analiz, upravlenie, optimizaciya [Optimization of business processes: documentation, analysis, management, optimization]. St. Petersburg: Azbuka. (in Russian)

26. Chornobay L.I., Duma O.I. (2013) Biznes-protsesy pidpryiemstva: zahalna kharakterystyka ta ekonomichna sut [Business processes of the enterprise: general characteristics and economic essence]. Proceedings of Management and entrepreneurship in Ukraine: stages of formation and problems of development: a collection of scientific papers, pp. 125-131.

\section{Список використаних джерел:}

1. Zaika S. Features of analysis of business processes of enterprises. Управління ресурсним забезпеченням господарської діяльності підприсмств реального сектору економіки : матеріали VI Всеукраїнської науково-практичної Інтернет-конференції 3 міжнародною участю, 17 листопада 2021 р. Полтава : ПДАУ, 2021. С. 301-302.

2. Zaika O. Basic principles of business process reengineering. Управління ресурсним забезпеченням господарської діяльності підприємств реального сектору економіки : матеріали VI Всеукраїнської науково-практичної Інтернет-конференції 3 міжнародною участю, 17 листопада 2021 р. Полтава : ПДАУ, 2021. С. 329-330.

3. Андерсен Б. Бизнес-процессы. Инструменты совершенствования / пер с англ. С.В. Ариничева. Москва : Стандарты и качество, 2010. 272 с.

4. Бабак О.А. Реінжиніринг як сучасний інструмент інноваційної діяльності підприємств. Економічний вісник ПереяславХмельницького ДПУ. 2011. № 17/1. С. 55-60.

5. Биннер Х. Управление организациями и производством: от функционального менеджмента к процессному / пер. с нем. Москва : Альпина Паблишерз, 2010. 282 с.

6. Виноградова О.В. Реінжиніринг бізнес-процесів у сучасному менеджменті : монографія. Донецьк, 2005. 195 с.

7. Грибан С.В. Оцінка ефективності реінжинірингу бізнес-процесів як інструмента антикризового управління. Агросвіт. 2015. № 2. C. $50-54$.

8. Заїка С.О., Грідін О.В. Особливості діагностики ефективності менеджменту. Вісник ХНТУСГ. Економічні науки. 2016. Вип. 174. С. 199-206.

9. Іпполітова І.Я. Ефективність здійснення реінжинірингу бізнес-процесів на підприємстві. Глобальні та національні проблеми економіки. 2016. Вип. 13. С. 264-270.

10. Ковальов А.І. Підвищення ефективності антикризового управління в корпоративному секторі на основі реінжинірингу бізнес-процесів. Вісник соціально-економічних досліджень. 2014. № 3(54). С. 124-130.

11. Ковтун Т.А., Дмитриева Л.В. Реинжиниринг бизнес-процессов с позиций методологий управления проектами. Управление развитием сложных систем. 2017. № 30. С. 44-49. 
12. Когут Ю.О. Модель реінжинірингу бізнес-процесів підприємства. Бізнес Інформ. 2011. № 10. С. 65-69.

13. Котлик А.В. Побудова системи показників для оцінки конкурентоспроможності бізнес-процесів підприємства. Управління розвитком. 2011. № 21(118). С. 30-32.

14. Крупа К.В. Реінжиніринг - гідна відповідь на виклики оточення. Актуальні проблеми економіки. 2011. № 10. С. $443-446$.

15. Лепейко T.I., Котлик А.В. Реінжиніринг бізнес-процесів : навчально-практичний посібник у схемах і таблицях. Харків : XHEУ, 2009. $80 \mathrm{c}$.

16. Любарська В.М. Правила виділення бізнес-процесів в організації. Матеріали конференції «Проблеми і перспективи розвитку інформаційних систем і технологій в економіці», присвяченої 40-річчю утворення кафедри інформаційних систем. Управління розвитком. 2004. № 2. Спецвипуск. С. 46-48.

17. Мазнєв Г.С., Заїка С.О., Грідін О.В. Антикризове управління як сфера бізнес-адміністрування. Науковий вісник УжНУ. Серія «Міжнародні економічні відносини та світове господарство». 2016. Вип. 10. С. 25-32.

18. Парсяк В.Н. Управління бізнес-процесами - інструмент підвищення ефективності організацій. Актуальні проблеми економіки. 2011. № 7. С. 131-138.

19. Реінжиніринг бізнес-процесів як сучасний метод управління стратегічними змінами на підприємстві / Л.М. Сакун, Л.В. Сухомлин, Л.В. Різніченко, Б.О. Вєлькін. Економіка і організація управління. 2020. № 2(38). С. 81-97.

20. Скнарь А. Контролінгові аспекти реінжинірингу бізнес-процесів підприємства. Банківська справа. 2009. № 3. С. 81-87.

21. Таранюк Л.М. Методологія реінжинірингу бізнес-процесів промислових підприємств. Механізм регулювання економіки. 2011. № 1. С. 111-119.

22. Таранюк Л.М., Запорожченко О.М. Організаційні засади проведення реінжинірингу бізнес-процесів підприємства. Механізм регулювання економіки. 2011. № 4. С. 122-133.

23. Уллах Ф., Робсон М. Практическое руководство по реинжинирингу бизнес-процессов. URL: http://iso.staratel.com/ BPRI/ ReIngBP.htm.

24. Хаммер М., Чампи Дж. Реинжиниринг корпорации: Манифест революции в бизнесе / пер. с англ. Ю.Е. Корнилович. Москва : Манн, Иванов и Фербер, 2010. 287 с.

25. Харрингтон Дж., Эсселинг К.С., Нимвеген Ван Х. Оптимизация бизнес-процессов: документирование, анализ, управление, оптимизация / пер. с англ. Санкт-Петербург : Азбука ; БМикро, 2011. 328 с.

26. Чорнобай Л.І., Дума О.І. Бізнес-процеси підприємства: загальна характеристика та економічна суть. Менеджмент та підприємництво в Украйні: етапи становлення і проблеми розвитку. 2013. С. 125-131.

Заїка Світлана, Харчевнікова Лілія, Заїка Олена Державний біотехнологічний університет

\section{РЕІНЖИНІРИНГ БІЗНЕС-ПРОЦЕСІВ ЯК ІНСТРУМЕНТ ЕФЕКТИВНОГО УПРАВЛІННЯ ПІДПРИЕМСТВАМИ}

У менеджменті існує багато управлінських підходів, які дають змогу підвищити показники ефективності діяльності підприємства. При иьому пріоритетним напрямом розвитку підприємств є здійснення інноваційної діяльності. Для досягнення успіху у иүій сфері підприємства змінюють підходи до управління, організаційні структури та моделі бізнесу. Утім, в умовах постійного загострення конкурентної боротьби досягнення високих показників діяльності підприємства щуонайкраще забезпечується за рахунок реінжинірингу бізнес-проиесів. Інноваційність реінжинірингу полягає у тому, щзо він поєднує використання прерогатив комп'ютерних технологій, технологій управління людськими ресурсами та змінами бізнес-процесів. У нинішніх умовах господарювання швидкість реакиії всіх підсистем підприємства та ефективність операцій мають особливе значення тає необхідною умовою його ефективного функціонування в умовах постійного загострення конкуренції. У иій ситуації реінжиніринг є найбільш результативним, адже сприяє підвищенню ефективності діяльності підприємства за рахунок зміни бізнес-моделі, яку воно використовує. Отже, вивчення процедур реінжинірингу, його принциипів $і$ завдань є актуальним в умовах сьогодення. Мета дослідження полягає в узагальненні теоретичних підходів до основних приниипів, видів $і$ завдань реінжинірингу бізнес-проиесів як інструменту ефективного управління підприємствами. Методологічною основою дослідження послужили праиі вітчизняних $і$ зарубіжних учених із проблем реінжинірингу та управління змінами підприємств. Реінжиніринг бізнес-прочесів є трунтовним переосмисленням і радикальним перепроєктуванням бізнес-процесів підприємств, які бажають значно поліпшити показники своєї діяльності. Його застосовують, коли необхідно прийняти обтрунтоване рішення про реорганізацію діяльності: радикальні перетворення, реструктуризацію бізнесу, заміну діючих структур управління на нові тощо. Завдяки ефективному використанню інструментів реінжсиірингу бізнес-прочесів можна зробити підприємство більш гнучким до змін зовнішнього середовища i більш стійким в умовах конкурентної боротьби. Таким чином, реінжиніринг бізнес-процесів передбачає рішучу, докорінну перебудову бізнес-проиесів та основ організації управління з метою істотного підвищення конкурентоспроможності підприємства на ринку та значного зростання ефективності діяльності підприємства як иілісної системи.

Ключові слова: реінжиніринг, бізнес прочеси, ефективне управління, показники діяльності підприємств, інноваџійність. 